Atmos. Chem. Phys., 20, 10427-10439, 2020

https://doi.org/10.5194/acp-20-10427-2020

(C) Author(s) 2020. This work is distributed under

the Creative Commons Attribution 4.0 License.

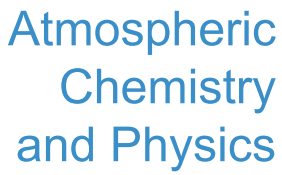

(c) (P)

\title{
Atmospheric mercury in the Southern Hemisphere - Part 2: Source apportionment analysis at Cape Point station, South Africa
}

\author{
Johannes Bieser $^{1}$, Hélène Angot ${ }^{2}$, Franz Slemr ${ }^{3,1}$, and Lynwill Martin ${ }^{4}$ \\ ${ }^{1}$ Helmholtz-Zentrum Geesthacht (HZG), Institute of Coastal Research, Max-Planck-Str. 1, 21502 Geesthacht, Germany \\ ${ }^{2}$ Institute of Arctic and Alpine Research, University of Colorado Boulder, Boulder, CO, USA \\ ${ }^{3}$ Max-Planck-Institut für Chemie (MPI), Air Chemistry Division, Hahn-Meitner-Weg 1, 55128 Mainz, Germany \\ ${ }^{4}$ South African Weather Service c/o CSIR, P.O. Box 320, Stellenbosch 7599, South Africa
}

Correspondence: Johannes Bieser (johannes.bieser@hzg.de) and Lynwill Martin (lynwill.martin@ weathersa.co.za)

Received: 22 January 2020 - Discussion started: 20 February 2020

Revised: 25 June 2020 - Accepted: 6 July 2020 - Published: 8 September 2020

\begin{abstract}
Mercury (Hg) contamination is ubiquitous. In order to assess its emissions, transport, atmospheric reactivity, and deposition pathways, worldwide $\mathrm{Hg}$ monitoring has been implemented over the past 10-20 years, albeit with only a few stations in the Southern Hemisphere. Consequently, little is known about the relative contribution of marine and terrestrial $\mathrm{Hg}$ sources, which is important in the context of growing interest in effectiveness evaluation of $\mathrm{Hg}$ mitigation policies. This paper constitutes Part 2 of the study describing a decade of atmospheric $\mathrm{Hg}$ concentrations at Cape Point, South Africa, i.e. the first long-term ( $>10$ years) observations in the Southern Hemisphere. Building on the trend analysis reported in Part 1, here we combine atmospheric $\mathrm{Hg}$ data with a trajectory model to investigate sources and sinks of $\mathrm{Hg}$ at Cape Point. We find that the continent is the major sink, and the ocean, especially its warm regions (i.e. the Agulhas Current), is the major source for $\mathrm{Hg}$.

Further, we find that mercury concentrations and trends from long-range transport are independent of the source region (e.g. South America, Antarctica) and thus indistinguishable. Therefore, by filtering out air masses from source and sink regions we are able to create a dataset representing a southern hemispheric background $\mathrm{Hg}$ concentrations. Based on this dataset, we were able to show that the interannual variability in $\mathrm{Hg}$ concentrations at Cape Point is not driven by changes in atmospheric circulation but rather due to changes in global emissions (gold mining and biomass burning).
\end{abstract}

\section{Introduction}

Mercury ( $\mathrm{Hg}$ ) is a toxic pollutant that is ubiquitous in the environment. Due to anthropogenic emissions, the amount of mercury in the atmosphere has increased 7-fold since preindustrial times (Amos et al., 2013). Mercury occurs in the atmosphere as gaseous oxidised mercury (GOM), particle bond mercury $(\mathrm{PBM})$, and predominantly $(\sim 95 \%)$ gaseous elemental mercury (GEM). Because of its atmospheric lifetime of about 1 year, once emitted into the atmosphere, GEM is transported on hemispheric and global scales (Slemr et al., 2018). Since 2017 usage and emissions of $\mathrm{Hg}$ are regulated under the UN Minamata Convention on Mercury (UNEP, 2013). This UN convention commits its member states to assess the current state of mercury pollution, to take actions to reduce mercury emissions, and to evaluate the success of these measures on a regular basis.

In order to assess the impact of emission reductions on the system it is necessary to better understand the sources and sinks driving atmospheric mercury cycling. Especially in the Southern Hemisphere, there has been a lack of longterm atmospheric observations that allow one to investigate and distinguish long-term trends from the natural variability in atmospheric $\mathrm{Hg}$ concentrations. So far, the only long-term observations in the Southern Hemisphere with measurements over more than 10 years have been and are performed at Cape Point (CPT), South Africa, where GEM has been measured since 1995 (Baker et al., 2002; Slemr et al., 2008). At CPT, for the first 10 years (September 1995 to December 2004) GEM concentrations showed a decreasing trend (Slemr et al., 
2008; Martin et al., 2017), while Martin et al. (2017) identified an increasing trend for the last 10 years (March 2007 to June 2015). Yet the reason for the observed trends is unclear, and there was no explanation for the change in sign from a decreasing to an increasing trend.

This work is presented in two accompanying papers where the first one (Slemr et al., 2020) focuses on long-term trends in the Southern Hemisphere over the last 10 years based on measurements at CPT and Amsterdam Island (AMS), which has been operational since 2012. The key finding of that paper is that since 2007 GEM concentrations at CPT seem to have been increasing, while no significant trend was found in the 2012-2017 period, both at CPT and AMS. The upward CPT trend in the 2007-2017 period seems to be driven by exceptionally low Hg concentrations in 2009 and aboveaverage concentrations in 2014.

Here, we combine 10 years of GEM (2007-2016) observations at CPT with calculated hourly backward trajectories in order to investigate sources and sinks for mercury and to quantify the impact of long-term changes in atmospheric circulation patterns on observed GEM concentrations at CPT. The aim of this study as follows:

- to distinguish between local changes at CPT and hemispheric GEM trends

- to identify source and sink regions for GEM at CPT

- to estimate the natural variability in GEM concentrations at CPT in order to distinguish them from other effects such as changing emissions.

This paper aims to improve our understanding of mercury cycling in the Southern Hemisphere. For this, we elaborate on the research question of whether concentrations and trends observed at CPT are dominated by local signals or representative of mercury cycling across large parts of the Southern Hemisphere. Based on backward trajectories and statistical modelling, we investigate source and sink regions for mercury observed at Cape Point and the impact of interannual variability on atmospheric transport patterns and emissions processes.

\section{Methodology}

\subsection{Observations}

This study is based on 10 years (2007-2016) of continuous GEM measurements at Cape Point (CPT; $34^{\circ} 21^{\prime} \mathrm{S}$, $18^{\circ} 29^{\prime} \mathrm{E}$ ), South Africa. The CPT measurement site is part of the GAW (Global Atmospheric Watch) baseline monitoring observatories of the World Meteorological Organization (WMO). It is located at the southernmost tip of the Cape Peninsula on top of the cliff at an altitude of $230 \mathrm{~m}$ (above seal level). There are no major local $\mathrm{Hg}$ sources, and the nearest city, Cape Town, is located $60 \mathrm{~km}$ to the north (see

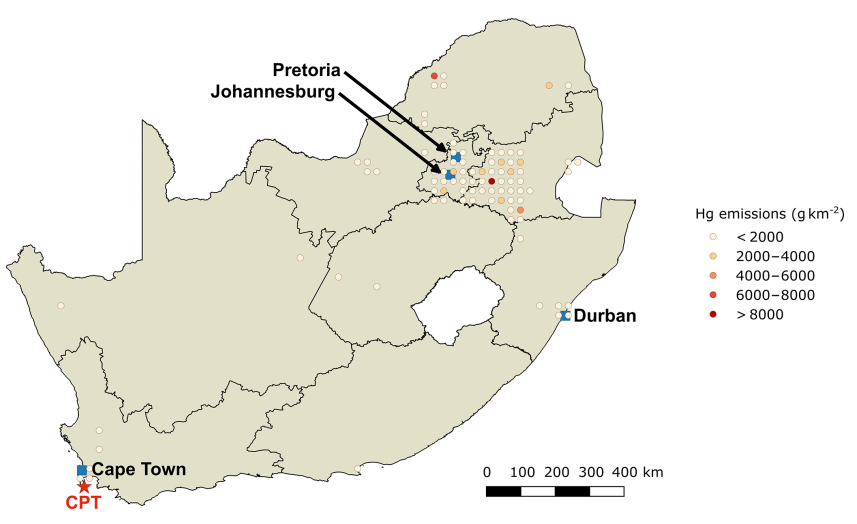

Figure 1. Location of the Cape Point site (CPT; red star), at the southernmost tip of the Cape Peninsula, and of known anthropogenic mercury emission sources (in $\mathrm{g} \mathrm{km}^{-2}$; Global Mercury Assessment 2018 emission inventory, Frits Steenhuisen, personal communication, July 2017) in South Africa. This map was made with QGIS.

Fig. 1). The station has been in operation since the 1970s, and, besides GEM, several other pollutants are measured on a regular basis. These include $\mathrm{CO}_{2}, \mathrm{CO}$, ozone, methane, and radon $\left({ }^{222} \mathrm{Rn}\right)$, which we use to substantiate the findings on mercury. A detailed description of the CPT station can be found in the accompanying paper (Slemr et al., 2020).

\subsection{Modelling}

GEM measurements at CPT are performed continuously with a 15 min sampling interval. The GEM measurements were aggregated to hourly averages, and for each hourly measurement an ensemble of $5 \mathrm{~d}$ backward trajectories was calculated using the Hybrid Single-Particle Lagrangian Trajectory Model (HYSPLIT) (Stein et al., 2015) (Fig. 2). For the hourly trajectory ensembles we used different starting altitudes in order to capture the model uncertainty due to the model's initial conditions. The HYSPLIT model was run for 10 years (2007 to 2016) using GDAS (Global Data Assimilation System) $0.5^{\circ} \times 0.5^{\circ}$ degree meteorological inputs based on the NCEP/NCAR reanalysis dataset (Kalnay et al., 1996, NOAA, 2004).

\subsection{Regionalisation}

The trajectories were categorised into six source regions depending on their travel path (Fig. 3, Table 1). These categories are as follows:

- Local. Air parcels which travelled less than $100 \mathrm{~km}$ absolute distance to CPT over the last $4 \mathrm{~d}$ are considered to be local air masses.

- Continental. These are air parcels that spend more than $80 \%$ of travel time over the African continent during the last $4 \mathrm{~d}$. 


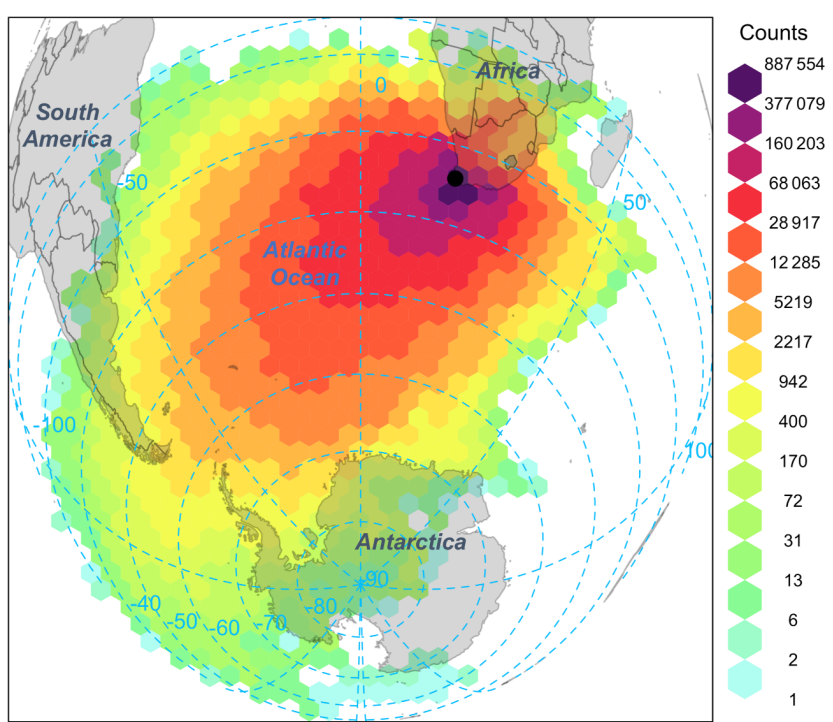

Figure 2. Origin of air masses influencing the Cape Point site (black dot). Gridded back-trajectory frequencies using an orthogonal map projection with hexagonal binning. The tiles represent the number of incidences. The 2007-2016 hourly back trajectories were computed using the HYSPLIT model (Stein et al., 2015), and the figure was made using the $\mathrm{R}$ package openair (Carslaw and Ropkins, 2012).

- Eastern Ocean These are air parcels which did not travel over land and did not go west of $30^{\circ} \mathrm{E}$ within the last $4 \mathrm{~d}$.

- South American. These are air parcels which were west of $30^{\circ} \mathrm{W}$ within the last $4 \mathrm{~d}$.

- Antarctic. These are air parcels which were south of $55^{\circ} \mathrm{S}$ within the last $4 \mathrm{~d}$.

- Atlantic. These are air parcels which do not fall within the other categories and spend more than $80 \%$ of the time over the Atlantic Ocean. This category makes up the majority of all trajectories.

The categorisation of air parcels depends on the definition of regions of origin and the travel time chosen for the algorithm. We calculated $5 \mathrm{~d}$ backward trajectories and experimented with different cutoff values to determine the source regions of the air masses (Table 1). For this study we chose a cutoff time of $4 \mathrm{~d}$ to determine long-range transport from Antarctica and South America. However, the choice of cutoff times of 3 or $5 \mathrm{~d}$ did not change the conclusions of our study. This decision is based on tests with different cutoff times and on the fact that the uncertainty in the trajectories grows with travel time (Engström and Magnusson, 2009). Moreover, air parcels are often a mixture of different source regions (e.g. Atlantic/Continental). As an additional test for the calculated categorisation we used secondary parameters such as ${ }^{222} \mathrm{Rn}$,

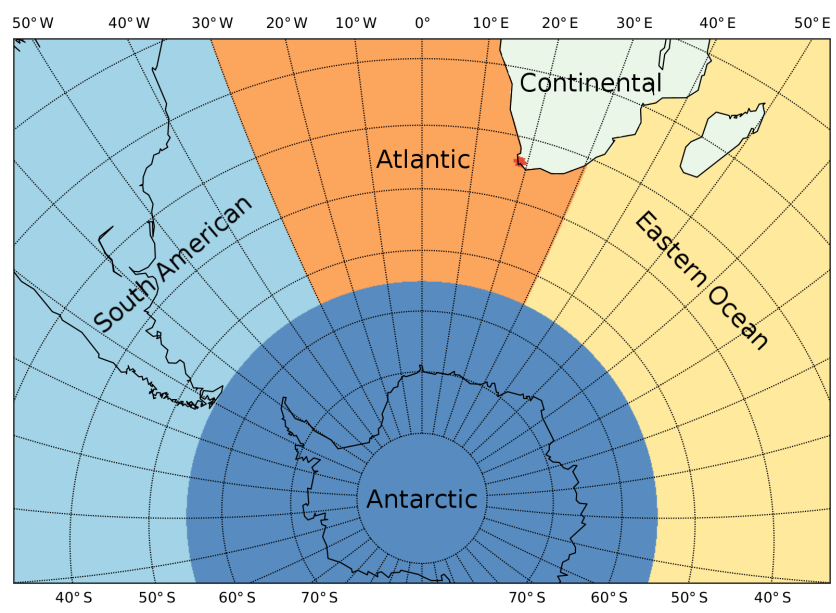

Figure 3. Depiction of the regionalisation used for this study: Local (red), Continental (light green), Eastern Ocean (yellow), South American (turquoise), Antarctic (blue), and Atlantic (orange).

$\mathrm{CO}, \mathrm{CO}_{2}, \mathrm{CH}_{4}$, and $\mathrm{O}_{3} .{ }^{222} \mathrm{Rn}$ is a radioactive gas of predominantly terrestrial origin with a half-life of $3.8 \mathrm{~d}$. Thus, high ${ }^{222} \mathrm{Rn}$ concentrations mark air masses which recently passed over the continent such as Continental and Local. Other examples are the distinction of long-range transport from South America from Atlantic air masses. Here, we would also expect higher concentrations of other anthropogenic pollutants (e.g. $\mathrm{CO}_{2}, \mathrm{CH}_{4}$ ).

\subsection{Identification of source/sink regions}

In order to evaluate source and sink regions we calculated the 10th and 90th percentile of GEM measurements for each season - seasons being defined as 3-month intervals: DJF (summer), MAM (autumn), JJA (winter), and SON (spring). This seasonal filter proved to be necessary to remove the annual cycle in GEM concentrations driven (among others) by the seasonality of emissions, planetary boundary layer height, and transport patterns. Furthermore, we filtered out mercury depletion events, of unknown origin (Brunke et al., 2010), which were defined as hourly average GEM concentrations of less $0.25 \mathrm{ng} \mathrm{m}^{-3}$.

For the source/sink region analysis, we interpolated hourly trajectory locations onto a polar stereographic grid centred over the South Pole and calculated the total number of trajectories travelling through each grid cell over the 10-year (2007-2016) period. We then performed the same procedure for the trajectories of the 10th and 90th percentile GEM concentrations. By dividing these percentile maps by the total number of trajectories travelling through each grid cell, we created maps indicating the regional prevalence of high and low GEM concentrations. In the theoretical case of perfectly homogeneous, evenly distributed sources and sinks, each grid cell would have a value of 0.1 indicating that $10 \%$ of all air parcels in each grid cell belong to the $10 \%$ high- 
Table 1. Impact of travel time cutoff on air parcels source region categorisation. Total and relative allocation of trajectories to each source region depending on air parcel travel time.

\begin{tabular}{lrrrrrr}
\hline Days & Antarctic & S. America & Continental & Eastern O. & Atlantic & Local \\
\hline 2 & 1778 & 150 & 14580 & 5930 & 143478 & 1760 \\
& $(1 \%)$ & $(<1 \%)$ & $(9 \%)$ & $(4 \%)$ & $(86 \%)$ & $(1 \%)$ \\
\hline 3 & 11800 & 3614 & 10596 & 7842 & 132876 & 926 \\
& $(7 \%)$ & $(2 \%)$ & $(6 \%)$ & $(5 \%)$ & $(79 \%)$ & $(1 \%)$ \\
\hline 4 & 26696 & 12756 & 7928 & 7882 & 111770 & 550 \\
& $(16 \%)$ & $(8 \%)$ & $(5 \%)$ & $(5 \%)$ & $(67 \%)$ & $(<1 \%)$ \\
\hline 5 & 39710 & 22960 & 5906 & 6876 & 91666 & 370 \\
& $(24 \%)$ & $(14 \%)$ & $(4 \%)$ & $(4 \%)$ & $(55 \%)$ & $(<1 \%)$ \\
\hline
\end{tabular}

est/lowest GEM observations. Deviations from this uniform distribution are then interpreted as source/sink regions for high/low GEM concentrations. For example, a value of 0.2 indicates that twice as many high/low GEM concentrations originate from a given grid cell compared to a uniform distribution.

To better distinguish the 10th and 90th percentile plots, we chose opposite colour schemes for the 10th and 90th percentile plots. In the case of the 90th percentile plots, red colour indicates source regions for high GEM concentrations (i.e. $>0.1$ ), while blue colour indicates the absence of sources in this region (Fig. 4a). For the 10th percentile plots, blue colour indicates sink regions for GEM concentrations (Fig. 4b), while red colour indicates the absence of sinks. It is important to note that an absence of sources is not equal to the presence of sinks and vice versa. Figure 4 gives an example of these plots for air masses attributed to the Atlantic category for ${ }^{222} \mathrm{Rn}$ measurements. This plot serves as an evaluation of the regionalisation algorithm. It can be seen that high ${ }^{222} \mathrm{Rn}$ concentrations are found only in air masses that travelled over the continent (Fig. 4a). Similarly, Fig. 4b depicts the fact that no measurements with low ${ }^{222} \mathrm{Rn}$ concentrations were found in air masses that travelled along the coast line, indicating an impact of terrestrial sources. Finally, this procedure is sensitive to the total number of trajectories travelling through a grid cell, which leads to low signal-tonoise ratios in the outskirts of the plot where only a few trajectories originate at all. We used a cutoff value of 10 hits and discarded all grid cells with fewer hits, but this still leads to a few nonsignificant hotspots at the outskirts of the domain (e.g. Fig. 4a in Antarctica).

\section{Results and discussion}

In this section we use backward trajectories of the 5th and 95th percentile GEM concentrations observed at Cape Point to identify the major source and sink regions for mercury (Sect. 3.1 Source and sink regions). We find that the Eastern Ocean with the warm Agulhas Current is the major source region, and the continent is the major sink region. We then compare the regional patterns of GEM with other pollutants (Sect. 3.2 Comparison of regionalised data) and find that GEM shows a distinct pattern compared to pollutants of terrestrial, anthropogenic and photochemical origin. In Sect. 3.3 Regional trends, we investigate distinct mercury trends for each region. We find that air masses from long-range transport (South America, Antarctica) show no distinct trends, which indicates that they are representative of the SH background. In Sect. 3.4 Regional abundance, we investigate what impact changing atmospheric circulation may have on the GEM trend observed at Cape Point and found it to be negligible. Instead we find that the annual average GEM concentrations depend on the regions with highest (Eastern Ocean) and lowest (Continental) GEM concentrations in air masses. Finally, in Sect. 3.5 Interannual variability, we try to explain the interannual variability in GEM concentrations observed at Cape Point with changes in global emissions. We show that biomass burning and gold mining emissions can explain years with exceptionally high (2014) or low (2009) GEM concentrations.

\subsection{Source and sink regions}

Figure 5 shows the 10th and 90th percentile maps for all GEM measurements over the whole period 2007-2016 (Fig. 5). It can be seen that low GEM concentrations originate almost exclusively from air masses which travelled over the continent (Fig. 5b). This result is in line with a cluster analysis performed by Venter et al. (2015), showing "air masses that had passed over the very sparsely populated semiarid Karoo region, almost directly to the north of CPT GAW, were mostly associated with [... ] lower GEM values". It is also consistent with the finding of Slemr et al. (2013) that southern Africa, based on GEM vs. ${ }^{222} \mathrm{Rn}$ correlations, is a net sink region. The reason for this is probably a mixture of near-zero emissions in the region and dry deposition onto the surface. 

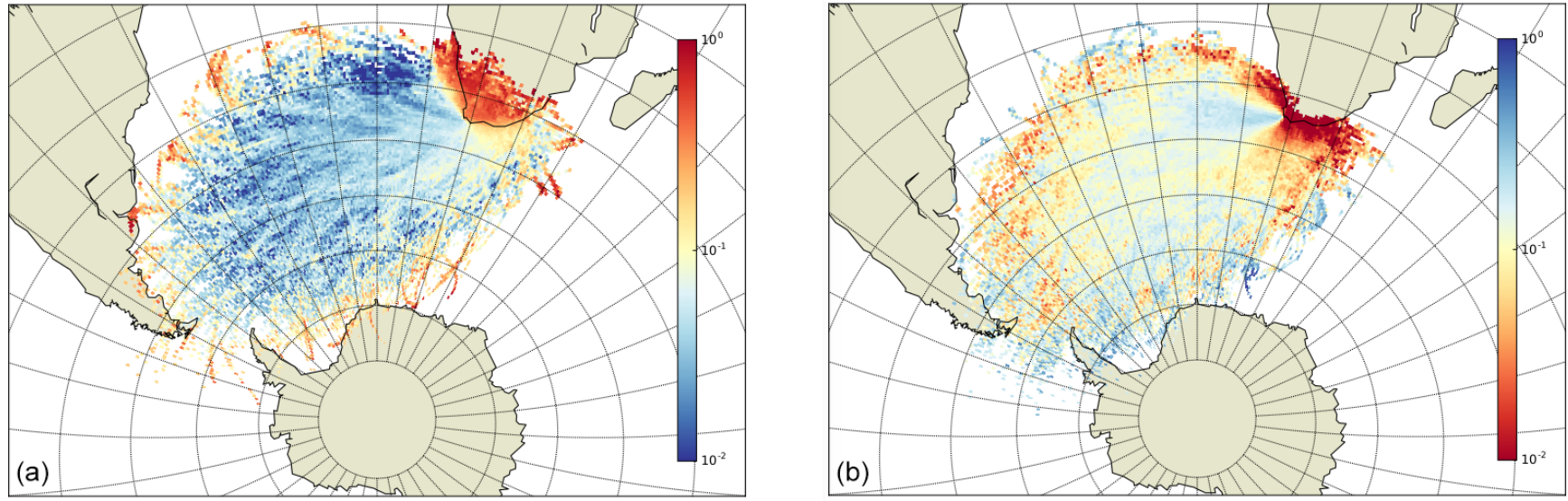

Figure 4. Distribution map for the (a) 90th percentile highest ${ }^{222} \mathrm{Rn}$ concentrations and the (b) 10th percentile lowest ${ }^{222} \mathrm{Rn}$ concentrations measured at Cape Point. Values are the dimensionless prevalence of air parcels of a given concentration percentile ranging from 0 to 1. This means that a homogeneous distribution of source and sink regions would lead to a plot with values of 0.1 everywhere. Deviations from this value indicate source and sink regions. See also the description in Sect. 2.4.
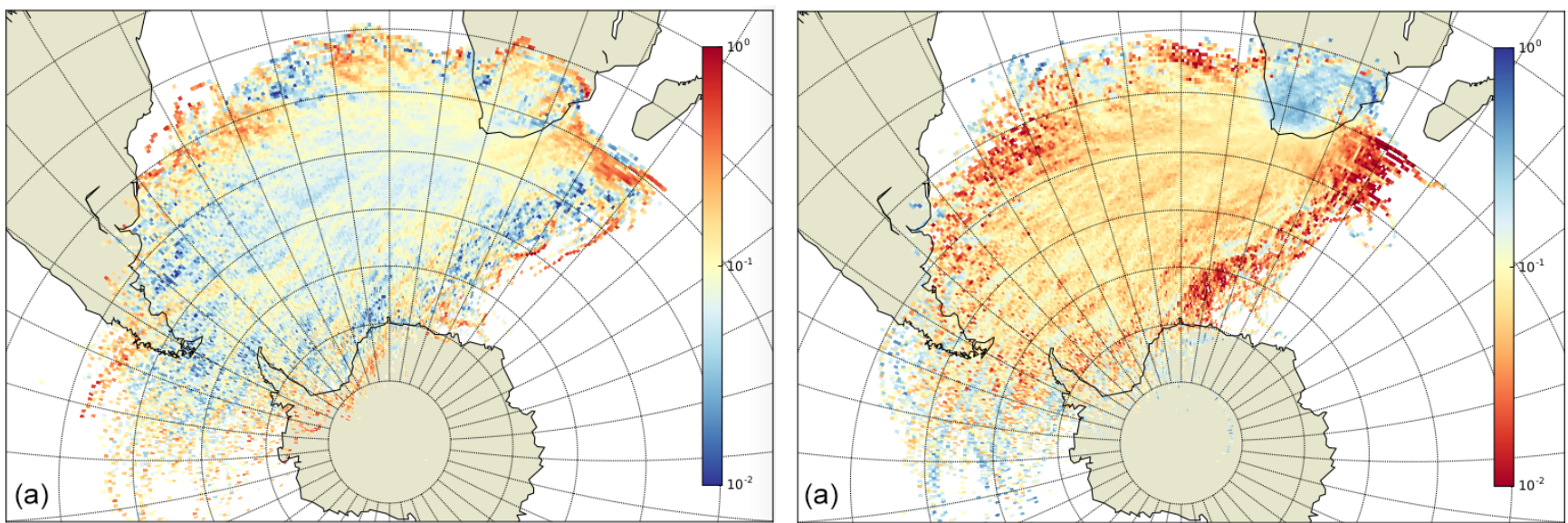

Figure 5. Prevalence of (a) highest (90th percentile) and (b) lowest (10th percentile) GEM concentrations using all hourly trajectories over 10 years.

Over the Atlantic Ocean, low GEM concentrations are in line with a uniform distribution with values mostly only slightly below the equilibrium value of 0.1 . The exception are air masses that travelled over the ocean east of Cape Point where almost no low concentration GEM measurements originated. Looking at the highest 90th percentile of GEM concentrations, air masses travelling over the ocean show a lower abundance with the exception of a patch east of Cape Point (Fig. 5a).

The picture becomes clearer when plotting trajectories independently for each of the previously defined regions (Fig. 6). It can be seen that the Eastern Ocean sector is the predominant source region of air masses with elevated GEM concentrations (Fig. 6e). In this region the Agulhas Current transports warm water from the Indian Ocean to the Atlantic Ocean, and we identify this warm current as a major mercury source in the region. For Continental air masses (Fig. 6b), certain source regions can be identified. These coincide with known major $\mathrm{Hg}$ emitters, mainly coal combustion for energy production (Fig. 1). For air masses representing longrange transport (Atlantic, South American, Antarctic), frequency values of the 90th percentile highest GEM concentrations are mostly around $10 \%$, indicating no specific sources or sinks in these regions.

Looking at the 10th percentile of lowest GEM concentrations, regional and Continental air masses can be identified as the single most important sink region (Fig. 7a, b). There are also some Continental areas with a high prevalence of low $\mathrm{Hg}$ concentrations attributed to the Atlantic sector. These can be interpreted as air parcels with a mixed Continental/Atlantic travel path that have been attributed as Atlantic air masses by the algorithm as they did not spend enough time over the continent to be attributed to this sector. Finally, there are no 


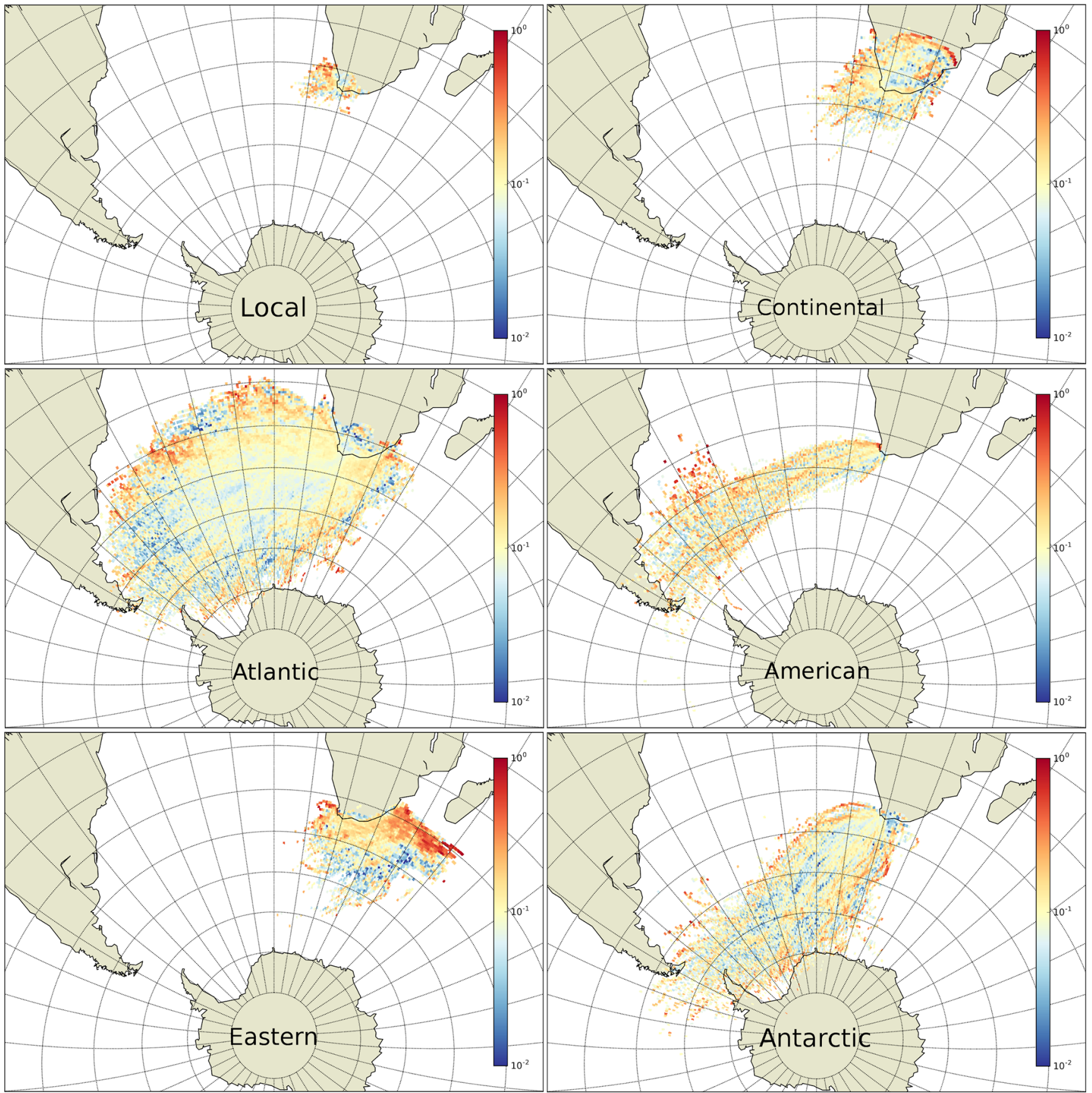

Figure 6. 90th percentile highest GEM concentrations for air masses from six source regions. Red colour means source regions; blue means an absence of emissions in that region.

air masses with low GEM concentrations originating from the Eastern Ocean sector (Fig. 7e).

To further investigate the processes behind the observed source and sink regions, we regard seasonal trajectory maps (Fig. 8). This analysis reveals that the high GEM concentrations associated with air masses from the Eastern Ocean occur mainly during austral spring and summer. This is consistent with the seasonal variation in GEM concentrations at
Cape Point shown in Fig. 2 of the companion paper (Slemr et al., 2020). Temperature or primary production and a related increase in evasion of GEM (with a large impact of reemissions of legacy $\mathrm{Hg}$ ) from the ocean are thus the likely reason for these observations. 


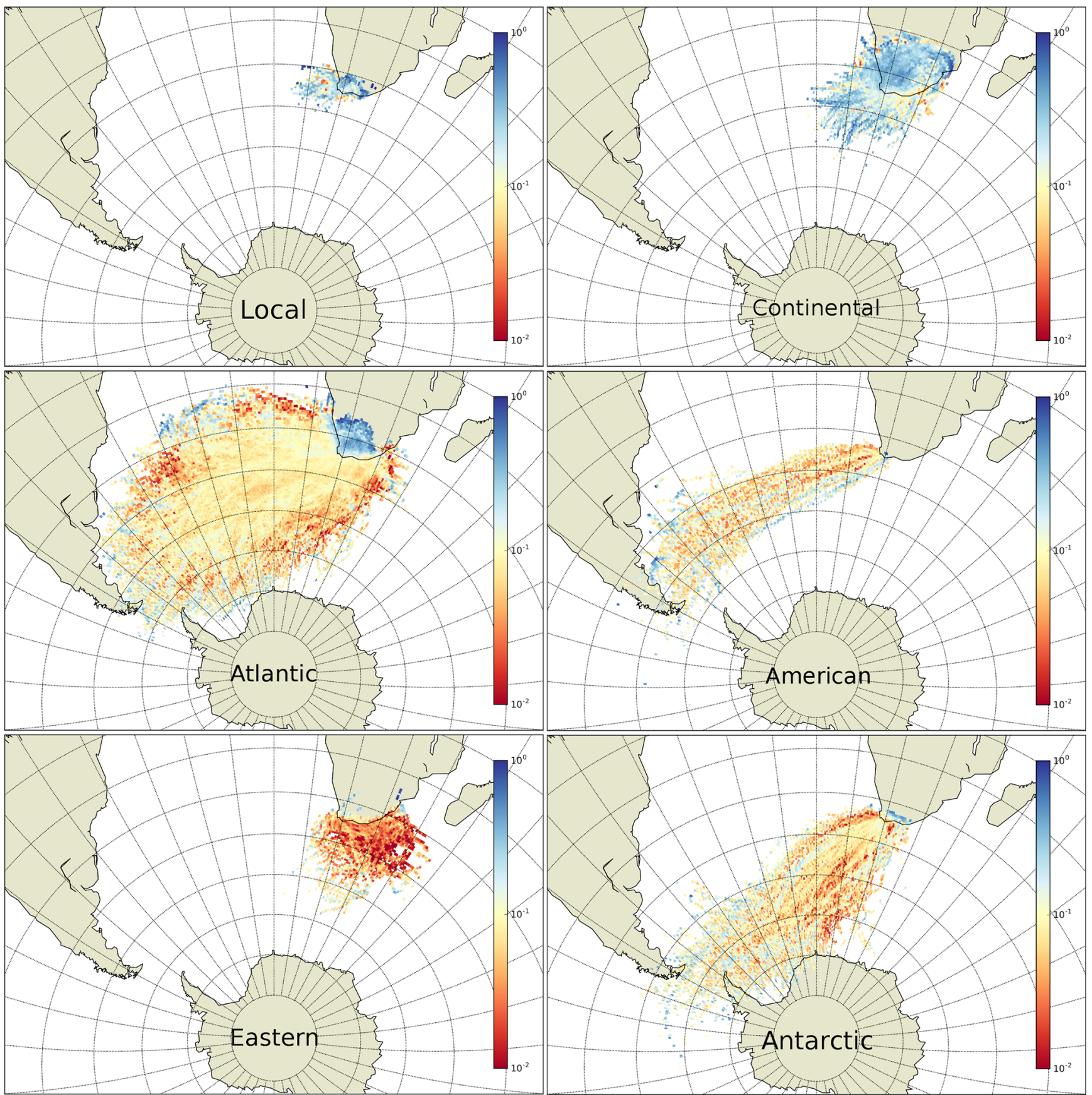

Figure 7. The 10th percentile lowest $\mathrm{Hg}$ concentrations for six source regions. Blue colours indicate sink regions, red colour absence of sinks. Low values are almost exclusively linked to Continental and Local air masses.

\subsection{Comparison of regionalised data}

Annual and monthly averages and medians for each source region of $4 \mathrm{~d}$ backward trajectory were calculated for GEM, $\mathrm{CO}_{2},{ }^{222} \mathrm{Rn}, \mathrm{CO}, \mathrm{CH}_{4}$, and $\mathrm{O}_{3}$. Here we compare the annual medians for all species and discuss the implications this comparison provides on regionalisation.
Table 2 shows the annual median GM concentrations. The highest annual median GEM concentrations were found for Eastern Ocean in 6 of 10 years. The lowest annual GEM concentrations were almost always either of Local or Continental origin. Annual median GEM concentrations for South American, Antarctic, and Atlantic lie close to each other and are in the middle in varying order. Annual average GEM concentrations behave similarly (not shown). 


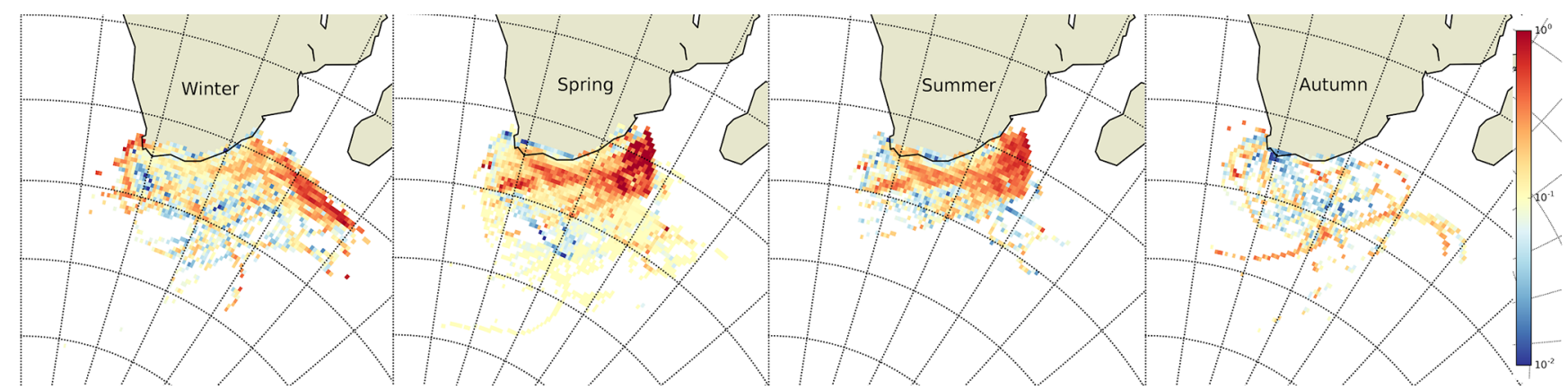

Figure 8. Seasonal breakdown of 90th percentile highest $\mathrm{Hg}$ concentrations from the Eastern Ocean source region. Highest Hg concentrations are mostly associated with austral spring and summer, which supports primary production as a potential source for oceanic $\mathrm{Hg}$ releases.

Table 2. Annual median GEM concentrations.

\begin{tabular}{crrrrrr}
\hline Year & Antarctic & South America & Continental & Eastern Ocean & Atlantic & Local \\
\cline { 2 - 7 } & \multicolumn{7}{c}{ Annual median GEM concentration $\left(\right.$ in ng m $^{-3}$ ), number of measurements } \\
\hline 2007 & $0.975,2406$ & $0.968,1388$ & $1.003,412$ & $1.046,378$ & $0.983,6946$ & $0.982,39$ \\
2008 & $0.976,1939$ & $0.994,811$ & $0.992,550$ & $1.047,453$ & $1.002,7903$ & $0.883,10$ \\
2009 & $0.910,2457$ & $0.904,944$ & $0.904,950$ & $0.933,544$ & $0.908,9482$ & $1.025,27$ \\
2010 & $0.995,2237$ & $0.982,1010$ & $0.929,918$ & $1.036,706$ & $0.996,10438$ & $1.084,18$ \\
2011 & $0.984,1874$ & $0.952,941$ & $0.978,890$ & $1.006,1282$ & $0.979,8851$ & $0.964,69$ \\
2012 & $1.074,2576$ & $1.077,1436$ & $1.035,453$ & $1.063,541$ & $1.068,10012$ & $1.030,62$ \\
2013 & $1.048,2523$ & $1.057,1260$ & $0.911,555$ & $1.069,191$ & $1.029,8069$ & $0.938,48$ \\
2014 & $1.057,2309$ & $1.079,947$ & $1.045,943$ & $1.206,929$ & $1.098,10791$ & $1.090,92$ \\
2015 & $1.009,2330$ & $1.009,1020$ & $0.992,546$ & $0.987,482$ & $0.998,11486$ & $1.017,46$ \\
2015 & $1.030,2206$ & $1.024,990$ & $0.986,612$ & $1.055,740$ & $1.015,9935$ & $0.934,72$ \\
\hline
\end{tabular}

Table 3 shows the annual median ${ }^{222} \mathrm{Rn}$ concentrations. The highest ${ }^{222} \mathrm{Rn}$ annual median concentrations were found for the regions Continental or Local, as expected for a radioactive trace gas of almost exclusively terrestrial origin and half-life of 3.8 d (Zahorowski et al., 2004). The lowest and second lowest ${ }^{222} \mathrm{Rn}$ concentrations were found in air masses attributed to South American or Antarctic. Atlantic median average concentrations are somewhat higher than Antarctic and South American, but their interannual variation is the smallest of all. Eastern Ocean median concentrations are somewhat higher than the Atlantic ones, which is likely due to proximity of African continent. The average concentrations behave similarly.

The regionalised median annual mixing ratios of $\mathrm{CO}, \mathrm{CO}_{2}$, $\mathrm{CH}_{4}$, and $\mathrm{O}_{3}$ are shown in the Supplement. Annual medians of $\mathrm{CO}, \mathrm{CO}_{2}$, and $\mathrm{CH}_{4}$, all of predominantly terrestrial origin, behave similarly to those of ${ }^{222} \mathrm{Rn}$. Ozone, although not of terrestrial but of photochemical origin in $\mathrm{NO}_{x}$-rich environments, also fits this pattern because its mixing ratios are highest in Local or Continental air masses where the highest $\mathrm{NO}_{x}$ mixing ratios are expected. Annual averages behave similarly to annual medians.

In summary GEM, with highest concentrations in air masses attributed mostly to Eastern Ocean and the lowest one found either in Local or Continental, shows a pattern opposite to all the other species mentioned above. Its different pattern clearly shows that its sources are predominantly oceanic and the sinks terrestrial. The results reported above apply for regionalisation using $4 \mathrm{~d}$ backward trajectories. Regionalisation with 3 or $5 \mathrm{~d}$ backward trajectories provides similar results.

\subsection{Regional trends}

Table 4 shows the regionalised trends calculated from the monthly median concentrations or mixing ratios. Regionalised trends for GEM, $\mathrm{CO}_{2},{ }^{222} \mathrm{Rn}, \mathrm{CO}, \mathrm{CH}_{4}$, and $\mathrm{O}_{3}$ were calculated from regional monthly averages and medians using least-squares fit. Months with less than 10 measurements were not considered. This restriction applies mostly to the Local region, resulting in too few monthly values for trend calculation. The trends of ${ }^{222} \mathrm{Rn}$ and $\mathrm{O}_{3}$ are insignificant for all regions. The trend differences are tested for significance by comparison of averages (Kaiser and Gottschalk, 1972) using the slope and its uncertainty as an average and its standard deviation, respectively.

The trends of ${ }^{222} \mathrm{Rn}$ and $\mathrm{O}_{3}$ are insignificant for all regions. $\mathrm{CO}_{2}$ and $\mathrm{CH}_{4}$ upward trends are significant for all regions. The regional $\mathrm{CO}_{2}$ trends for the Antarctic and Atlantic 
Table 3. Annual median ${ }^{222} \mathrm{Rn}$ concentrations.

\begin{tabular}{rrrrrrr}
\hline Year & Antarctic & South America & Continental & Eastern Ocean & Atlantic & Local \\
\cline { 2 - 7 } & \multicolumn{5}{c}{ Annual median ${ }^{222}$ Rn concentration $\left(\right.$ in $^{2} \mathrm{mB} \mathrm{m}^{-3}$ ), number of measurements } \\
\hline 2007 & 294,2770 & 265,1584 & 804,432 & 685,376 & 350,8758 & 842,38 \\
2008 & 241,1492 & 283,604 & 2120,502 & 345,412 & 349,6940 & \\
2009 & 230,1982 & 275,840 & 1623,912 & 436,548 & 345,8306 & 1755,26 \\
2010 & 257,1942 & 315,780 & 2413,784 & 449,486 & 351,9126 & 1326,16 \\
2011 & 208,2546 & 288,1086 & 2464,1104 & 488,1288 & 370,10536 & 1612,88 \\
2012 & 184,2658 & 231,1510 & 1483,548 & 413,866 & 345,10636 & 3273,56 \\
2013 & 252,3104 & 174,1650 & 2335,630 & 489,504 & 329,10966 & 1709,56 \\
2014 & 249,2296 & 255,938 & 2195,948 & 532,968 & 337,10928 & 1737,74 \\
2015 & 339,2216 & 338,1030 & 1786,642 & 718,564 & 348,11510 & 803,52 \\
2015 & 244,2346 & 209,1296 & 2667,626 & 530,802 & 385,10998 & 1656,78 \\
\hline
\end{tabular}

are comparable at 2.18-2.20 $\mathrm{ppm} \mathrm{yr}^{-1}$. The trends for Continental and Eastern Ocean are also comparable, although significantly higher, at $2.21-2.25 \mathrm{ppm} \mathrm{yr}^{-1}$. The trend for South American is the smallest of all. The $\mathrm{CH}_{4}$ trends show the same pattern with the trend for South American being the smallest, too. The trends for Antarctic and Atlantic are comparable and somewhat higher. The trends for Continental and Eastern Ocean are highest and comparable. The similar pattern for $\mathrm{CO}_{2}$ and $\mathrm{CH}_{4}$ trends is consistent with terrestrial sources of these trace gases. The trend for $\mathrm{CO}$ is always downward, although significant only for the South American region when calculated both from monthly averages and medians.

Three source regions provide significant trends for GEM when calculated both from monthly averages and medians. The trends for Antarctic and South American air masses are comparable and significantly higher than the trend for the Atlantic region. This pattern is different from those of $\mathrm{CO}_{2}$ and $\mathrm{CH}_{4}$, with smaller trends for South American and higher ones for Atlantic and Antarctic. In summary, the patterns of GEM, $\mathrm{CO}_{2}$, and $\mathrm{CH}_{4}$ trend differences provide additional piece of evidence for an oceanic GEM source and are consistent with the patterns of annual medians presented in Sect. 3.2. We note that the overall trend of GEM concentrations is close to that for the Atlantic region to which twothirds of all GEM measurements are allocated.

\subsection{Regional abundance}

Air masses from long-range transport (Atlantic, Antarctic, South American) make up $90 \%$ of all air masses observed at Cape Point. Seasonally averaged observed concentrations from these regions show a high correlation with the averages of all observations at Cape Point, with $R^{2}$ values mostly above 0.9 (Table 5). Only Antarctic air masses during austral summer and autumn exhibit a lower correlation.

Air masses from the sectors Eastern Ocean and Continental on the other hand show very low correlations with the averages observed at Cape Point indicating that these air masses differ significantly from the rest. On average, transport from these two regions make up $10 \%$ of the air masses at Cape Point (Table 1). Their prevalence varies mostly only by 1 to 2 percentage points from year to year, with a peak of $10 \%$ Continental air masses in 2011. However, we found that the prevalence of air masses from source and sink regions is not the driver of the interannual variability in $\mathrm{Hg}$ concentrations at Cape Point (e.g. even with twice as much as average air masses from the sink region, 2011 was not a year with particularly low $\mathrm{Hg}$ concentrations) (Figs. 8, 9). Because of this and based on the comparison with measurements at Amsterdam Island (Slemr et al., 2020) we are confident that mercury concentrations observed at Cape Point are representative for the Southern Hemisphere background. Additionally, based on the presented work we are able to filter out the source and sink regions from the dataset for further analysis. Figure 10 depicts the whole GEM dataset with values from source and sink regions highlighted.

\subsection{Interannual variability}

The trend in GEM concentrations observed at Cape Point and the fact that it seemingly changed from increasing to stable between 2006 and 2017 is still unexplained (Slemr et al., 2020). Having shown that the observations at Cape Point are not dominated by regional processes, the question arises as to which large-scale processes modulate the signal on annual and decadal timescales.

At this point, our null hypothesis is that mercury concentrations in the Southern Hemisphere were stable over the last decade, but processes on global and hemispheric scales superimpose a (multi-)annual modulation on the signal. Based on our analysis so far, we can exclude changes in climatology as the cause for the interannual variability. Thus, in our opinion only global source processes remain as possible explanations for the observed anomaly. The identified processes are marine emissions, emissions from biomass burning, and artisanal small-scale (ASGM) gold mining, which are the major sources for mercury in the Southern Hemisphere. 
Table 4. Trends of GEM, $\mathrm{CO}_{2}, \mathrm{CH}_{4}$, and $\mathrm{CO}$ calculated by least-squares fit from monthly averages (a) and medians (m). Months with less than 10 measurements were not considered, which applies to most Local months. Trends of ${ }^{222} \mathrm{Rn}$ and $\mathrm{O}_{3}$ were not significant (ns) for all regions.

\begin{tabular}{|c|c|c|c|c|}
\hline Trace gas & Region & Slope & $N$, significance & Unit \\
\hline \multirow[t]{5}{*}{ GEM } & Antarctic & $\begin{array}{l}10.84 \pm 2.63(\mathrm{a}) \\
9.62 \pm 2.69(\mathrm{~m})\end{array}$ & $112,>99.9 \%$ & $\mathrm{pg} \mathrm{m}^{-3} \mathrm{yr}^{-1}$ \\
\hline & South American & $\begin{array}{l}10.16 \pm 2.74(\mathrm{a}) \\
10.15 \pm 2.80(\mathrm{~m})\end{array}$ & $111,>99.9 \%$ & \\
\hline & Continental & $\begin{array}{l}8.40 \pm 4.25(\mathrm{a}) \\
6.27 \pm 4.02(\mathrm{~m})\end{array}$ & $91, \mathrm{~ns}$ & \\
\hline & Eastern Ocean & $\begin{array}{l}5.20 \pm 3.77(\mathrm{a}) \\
6.33 \pm 3.80(\mathrm{~m})\end{array}$ & $67, \mathrm{~ns}$ & \\
\hline & Atlantic & $\begin{array}{l}8.64 \pm 2.59(\mathrm{a}) \\
8.13 \pm 2.54(\mathrm{~m})\end{array}$ & $115,>99 \%$ & \\
\hline \multirow[t]{5}{*}{$\mathrm{CO}_{2}$} & Antarctic & $\begin{array}{l}2.186 \pm 0.023(\mathrm{a}) \\
2.196 \pm 0.022(\mathrm{~m})\end{array}$ & $116,>99.9 \%$ & $\mathrm{ppm} \mathrm{yr}^{-1}$ \\
\hline & South American & $\begin{array}{l}2.171 \pm 0.025(\mathrm{a}) \\
2.180 \pm 0.022(\mathrm{~m})\end{array}$ & $116,>99.9 \%$ & \\
\hline & Continental & $\begin{array}{l}2.246 \pm 0.048(\mathrm{a}) \\
2.226 \pm 0.044(\mathrm{~m})\end{array}$ & $90,>99.9 \%$ & \\
\hline & Eastern Ocean & $\begin{array}{l}2.242 \pm 0.049(\mathrm{a}) \\
2.210 \pm 0.058(\mathrm{~m})\end{array}$ & $73,>99.9 \%$ & \\
\hline & Atlantic & $\begin{array}{l}2.182 \pm 0.023(\mathrm{a}) \\
2.196 \pm 0.019(\mathrm{~m})\end{array}$ & $119,>99.9 \%$ & \\
\hline \multirow[t]{5}{*}{$\mathrm{CH}_{4}$} & Antarctic & $\begin{array}{l}6.320 \pm 0.484(\mathrm{a}) \\
6.776 \pm 0.391(\mathrm{~m})\end{array}$ & $116,>99.9 \%$ & $\mathrm{ppb} \mathrm{yr}^{-1}$ \\
\hline & South American & $\begin{array}{l}5.789 \pm 0.528(\mathrm{a}) \\
6.712 \pm 0.395(\mathrm{~m})\end{array}$ & $118,>99.9 \%$ & \\
\hline & Continental & $\begin{array}{l}7.298 \pm 0.708(\mathrm{a}) \\
6.732 \pm 0.595(\mathrm{~m})\end{array}$ & $95,>99.9 \%$ & \\
\hline & Eastern Ocean & $\begin{array}{l}7.225 \pm 0.695(\mathrm{a}) \\
7.230 \pm 0.610(\mathrm{~m})\end{array}$ & $76,>99.9 \%$ & \\
\hline & Atlantic & $\begin{array}{l}6.670 \pm 0.486(\mathrm{a}) \\
6.840 \pm 0.388(\mathrm{~m})\end{array}$ & $119,>99.9 \%$ & \\
\hline \multirow[t]{5}{*}{$\mathrm{CO}$} & Antarctic & $\begin{array}{l}-1.166 \pm 0.385(\mathrm{a}) \\
-0.527 \pm 0.260(\mathrm{~m})\end{array}$ & $\begin{array}{l}115,>99 \% \text { (a) } \\
\text { ns (m) }\end{array}$ & $\mathrm{ppbyr}^{-1}$ \\
\hline & South American & $\begin{array}{l}-1.380 \pm 0.397(\mathrm{a}) \\
-0.731 \pm 0.281(\mathrm{~m})\end{array}$ & $\begin{array}{l}117,>99 \%(\mathrm{a}) \\
>95 \%(\mathrm{~m})\end{array}$ & \\
\hline & Continental & $\begin{array}{l}-1.027 \pm 0.823(\mathrm{a}) \\
-1.055 \pm 0.731(\mathrm{~m})\end{array}$ & $\begin{array}{l}92, \text { ns (a) } \\
\text { ns (m) }\end{array}$ & \\
\hline & Eastern Ocean & $\begin{array}{l}-0.010 \pm 0.816(\mathrm{a}) \\
-0.133 \pm 0.781(\mathrm{~m})\end{array}$ & $\begin{array}{l}75, \text { ns (a) } \\
\text { ns (m) }\end{array}$ & \\
\hline & Atlantic & $\begin{array}{l}-1.007 \pm 0.364(\mathrm{a}) \\
-0.506 \pm 0.271(\mathrm{~m})\end{array}$ & $\begin{array}{l}119,>95 \% \text { (a) } \\
\text { ns (m) }\end{array}$ & \\
\hline
\end{tabular}




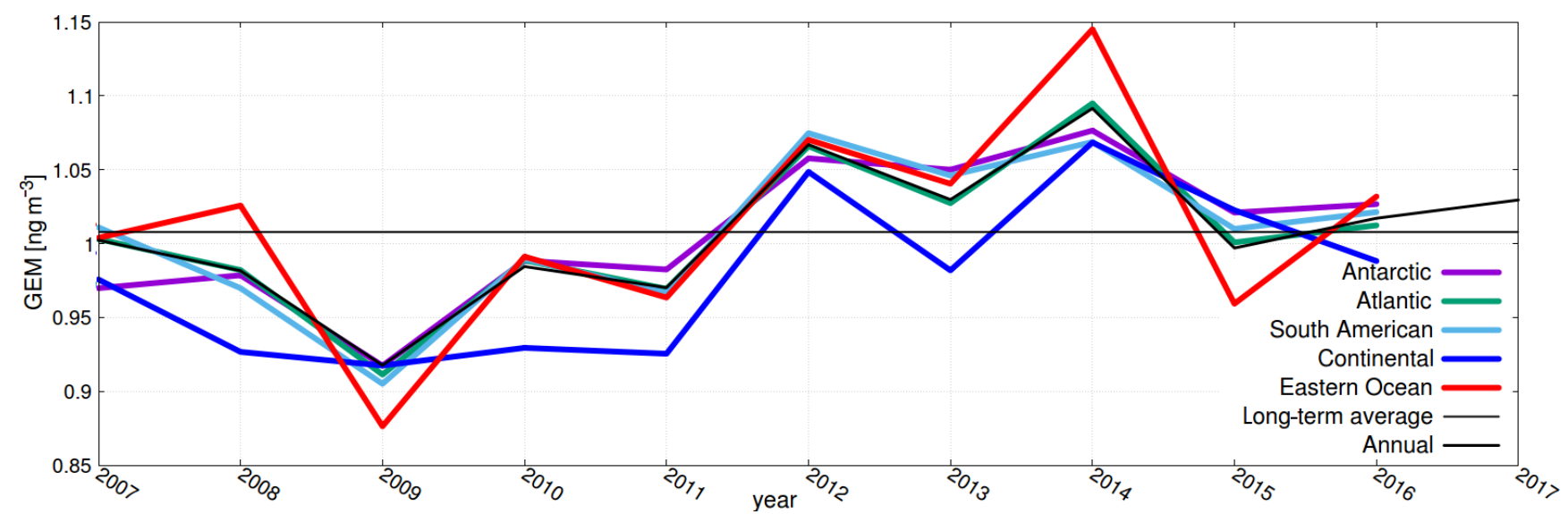

Figure 9. Annual average concentrations at Cape Point from 2007 to 2017 (black line) and regional averages (coloured lines). It can be seen that the minimum in 2009 and the maximum in 2014 is present in all source regions.

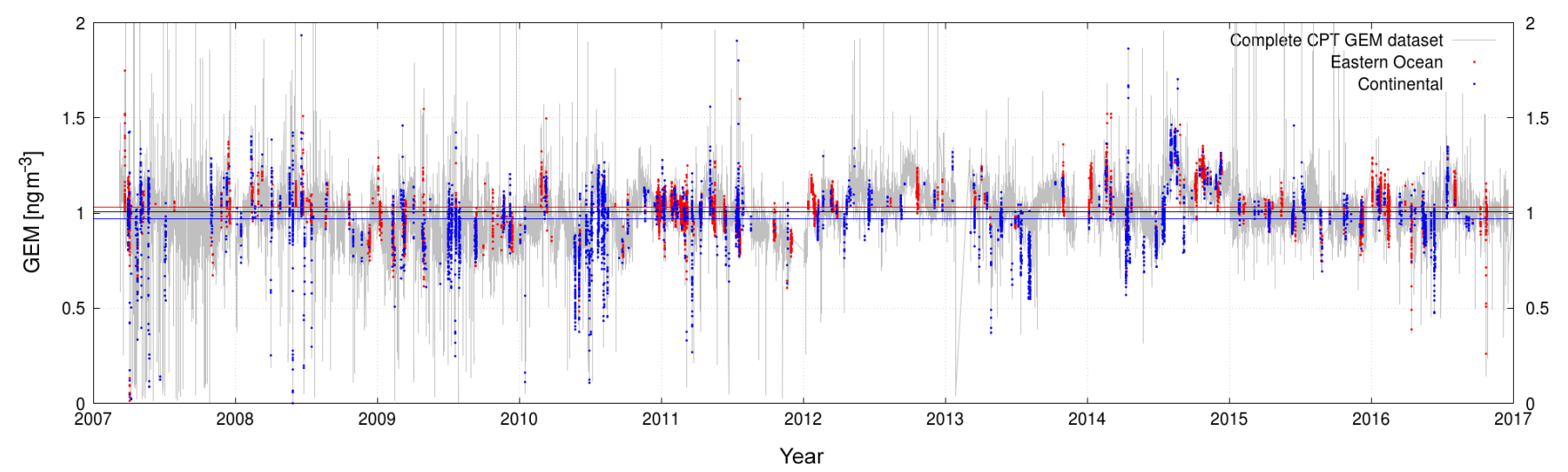

Figure 10. Complete Cape Point dataset (grey) with observations originating from source (red) and sink (blue) regions superimposed. The coloured $x$ axis parallel indicates the long-term average (black: complete dataset; red: source region; blue: sink region).

Especially, the low mercury concentrations observed in 2009 and the high values observed in 2014 seem to be at least partially a large-scale phenomenon. A screening of international observation networks also showed that Mace Head which is located in the Atlantic Ocean in the Northern Hemisphere - also has the lowest annual average mercury concentrations in 2009 and the highest in 2014 (GMOS, 2020; Weigelt et al., 2015). For the year 2009 the mercury emission inventory of Streets et al. (2019) postulates a sudden plummet in global gold mining activity. Comparing the annual anomaly from the 10 -year average, gold mining activity is correlated with observed GEM concentrations $(R=0.64)$. Similarly, we found a correlation with biomass burning in the Southern Hemisphere (mostly Africa) $(R=0.75)$ (Jiang et al., 2017). We removed air masses from the identified source and sink regions from the dataset and used a regression analysis to correct for changes in global gold mining and biomass burning emissions (Fig. 11). The resulting signal becomes relatively flat, with only two peaks remaining in 2012 and 2014.

\section{Conclusions}

Our goal was to improve the understanding of mercury cycling in the Southern Hemisphere. For this, we combined 10 years of GEM observations at Cape Point, South Africa, with hourly backward trajectories calculated with the Hybrid Single-Particle Lagrangian Trajectory (HYSPLIT) model. Our findings are as follows:

1. Overall the continent is a major sink region for mercury despite significant point sources, mostly linked to coal combustion.

2. Mercury emissions from the warm Agulhas Current to the south-east are a major source of elevated $\mathrm{Hg}$ concentration observed at Cape Point.

3. Separating the ground-based observations into air parcels from different source regions showed that mercury behaves opposite to known pollutants of terrestrial origin, implying the ocean as its major source. 
Table 5. Correlation coefficient $\left(R^{2}\right)$ of regional average concentrations with averages of all measurements at Cape Point. Values are based on monthly averages $(N=30)$. Antarctic, Atlantic, and South American air masses exhibit a high correlation with the overall mean concentrations observed at Cape Point.

\begin{tabular}{lrrrrr}
\hline & Annual & $\begin{array}{r}\text { Spring } \\
\text { (SON) }\end{array}$ & $\begin{array}{r}\text { Summer } \\
\text { (DJF) }\end{array}$ & $\begin{array}{r}\text { Autumn } \\
\text { (MAM) }\end{array}$ & $\begin{array}{r}\text { Winter } \\
(\mathrm{JJA})\end{array}$ \\
\hline Antarctic & 0.89 & 0.95 & 0.75 & 0.72 & 0.96 \\
South American & 0.95 & 0.95 & 0.91 & 0.95 & 0.97 \\
Continental & 0.39 & 0.54 & 0.05 & 0.59 & 0.33 \\
Eastern Ocean & 0.81 & 0.77 & 0.58 & 0.14 & 0.84 \\
Atlantic & 0.98 & 0.97 & 0.90 & 0.94 & 0.99 \\
\hline
\end{tabular}

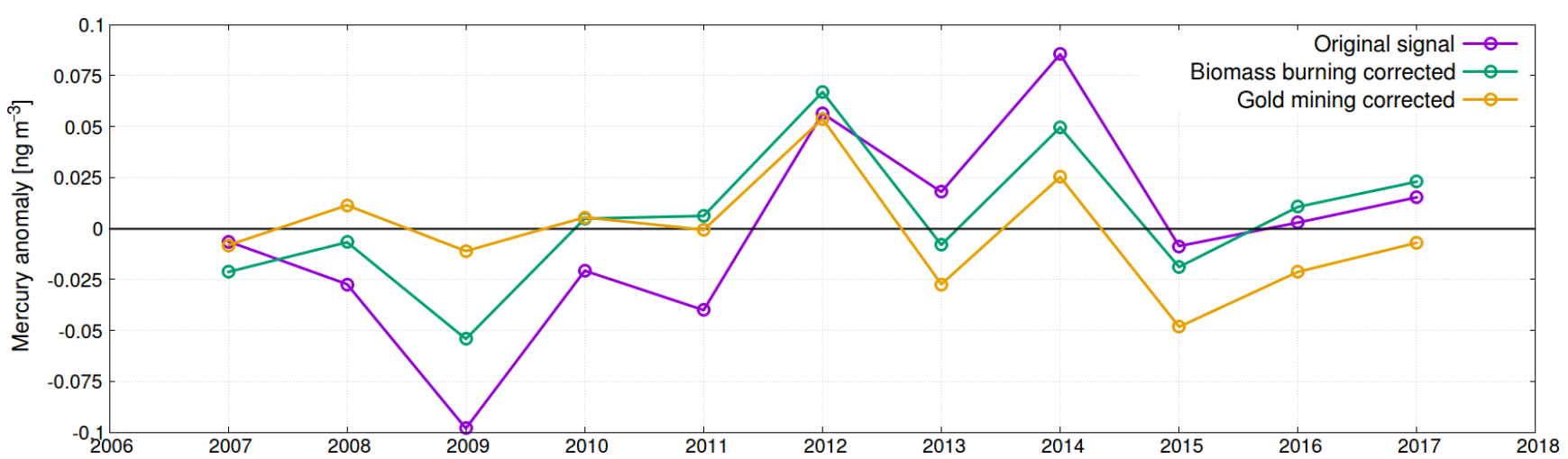

Figure 11. Annual anomaly from 10-year average mercury concentrations. Original dataset at Cape Point (purple), corrected for biomass burning emissions (green) (Jiang et al., 2017) and additionally corrected for gold mining emissions (orange) (Streets et al., 2019).

4. Mercury concentration in air masses from Antarctic, Atlantic, and South American origin were statistically almost indistinguishable. Thus, we interpret these observations as a good representation of the southern hemispheric background.

5. We find that the trends in GEM concentrations postulated in the past are probably an artefact of single years with unusually high (2014) or low (2009) GEM concentrations (see accompanying paper: Slemr et al., 2020). We have shown that these exceptional years could be partly explained by changes in global emissions from biomass burning and gold mining, two major sources of mercury in the Southern Hemisphere.

6. With the ocean being the main source of mercury in the Southern Hemisphere it can be expected that an increased air-sea flux due to larger concentration gradients will compensate reductions in global atmospheric emissions due to the Minamata Convention. With this in mind we emphasise the need for more research on marine mercury dynamics and air-sea exchange of mercury.
Data availability. Mercury observations at Cape Point are available via the GMOS data centre: http://sdi.iia.cnr.it/geoint/publicpage/ GMOS/gmos_monitor.zul (GMOS, 2020).

Supplement. The supplement related to this article is available online at: https://doi.org/10.5194/acp-20-10427-2020-supplement.

Author contributions. HA performed the HYSPLIT runs and investigated emission and satellite data. LM is responsible for the observations at Cape Point. FS was responsible for the statistical evaluation. JB is the main author of the manuscript and was responsible for linking data from model and observation. All authors worked collaboratively on the interpretation of the data.

Competing interests. The authors declare that they have no conflict of interest.

Acknowledgements. We want to thank NOAA for free access to the HYSPLIT model. This publication forms part of the output of the Biogeochemistry Research Infrastructure Platform (BIOGRIP) of the Department of Science and Innovation of South Africa as well as the newly formed South African Mercury Network (SAMNet). 
Lynwill Martin wishes to thank the CPT GAW team for providing the data on which this paper is based.

Special issue statement. This article is part of the special issue "Research results from the 14th International Conference on Mercury as a Global Pollutant (ICMGP 2019), MercOx project, and iGOSP and iCUPE projects of ERA-PLANET in support of the Minamata Convention on Mercury (ACP/AMT inter-journal SI)". It is not associated with a conference.

Financial support. This work has received funding under H2020SC5-15-2015 ERA-NET-Cofund grant no. 689443 "Strengthening the European Research Area in the domain of Earth Observation".

The article processing charges for this open-access publication were covered by a Research Centre of the Helmholtz Association.

Review statement. This paper was edited by Andreas Hofzumahaus and reviewed by two anonymous referees.

\section{References}

Amos, H. M., Jacob, D. J., Streets, D. G., and Sunderland, E. M.: Legacy impacts of all-time anthropogenic emissions on the global mercury cycle, Global Biogeochem. Cy., 27, 410-421, https://doi.org/10.1002/gbc.20040, 2013.

Baker, P. G. L., Brunke, E.-G., Slemr, F., and Crouch, A.: Atmospheric mercury measurements at Cape Point, South Africa, Atmos. Envron. 36, 2459-2465, 2002.

Brunke, E.-G., Labuschagne, C., Ebinghaus, R., Kock, H. H., and Slemr, F.: Gaseous elemental mercury depletion events observed at Cape Point during 2007-2008, Atmos. Chem. Phys., 10, 11211131, https://doi.org/10.5194/acp-10-1121-2010, 2010.

Carslaw, D. C. and Ropkins, K.: openair - An R package for air quality analysis, Environ. Modell. Softw., 27-28, 52-61, 2012.

Engström, A. and Magnusson, L.: Estimating trajectory uncertainties due to flow dependent errors in the atmospheric analysis, Atmos. Chem. Phys., 9, 8857-8867, https://doi.org/10.5194/acp9-8857-2009, 2009.

GMOS: Global Mercury Observation System, CNR-Institute of Atmospheric Pollution Research, Rome, Italy, available at: http://sdi.iia.cnr.it/geoint/publicpage/GMOS/gmos_monitor. zu, last access: 19 August 2020.

Jiang, Z., Worden, J. R., Worden, H., Deeter, M., Jones, D. B. A., Arellano, A. F., and Henze, D. K.: A 15-year record of $\mathrm{CO}$ emissions constrained by MOPITT CO observations, Atmos. Chem. Phys., 17, 4565-4583, https://doi.org/10.5194/acp17-4565-2017, 2017.

Kaiser, R. and Gottschalk, G.: Elementare Tests zur Beurteilung von Messdaten, Bibliographisches Institut, Mannheim, 1972.

Kalnay, E., Kanamitsu, M., Kistler, R., Collins, W., Deaven, D., Gandin, L., Iredell, M., Saha, S., White, G., Woollen, J., Zhu, Y., Chelliah, M., Ebisuzaki, W., Higgins, W., Janowiak, J., Mo, K. C., Ropelewski, C., Wang, J., Leetmaa, A., Reynolds, R., Jenne,
R., and Joseph, D.: The NCEP/NCAR 40-year reanalysis project, B. Am. Meteorol. Soc., 77, 437-470, 1996.

Martin, L. G., Labuschagne, C., Brunke, E.-G., Weigelt, A., Ebinghaus, R., and Slemr, F.: Trend of atmospheric mercury concentrations at Cape Point for 1995-2004 and since 2007, Atmos. Chem. Phys., 17, 2393-2399, https://doi.org/10.5194/acp17-2393-2017, 2017.

NOAA Air Resources Laboratory (ARL): available at: http://ready. arl.noaa.gov/gdas1.php (last access: 1 March 2019), Tech. Rep., 2004.

Slemr, F., Brunke, E.-G., Labuschagne, C., and Ebinghaus, R.: Total gaseous mercury concentrations at the Cape Point GAW station and their seasonality, Geophys. Res. Lett., 35, L11807, https://doi.org/10.1029/2008GL033741, 2008.

Slemr, F., Brunke, E.-G., Whittlestone, S., Zahorowski, W., Ebinghaus, R., Kock, H. H., and Labuschagne, C.: ${ }^{222}$ Rn-calibrated mercury fluxes from terrestrial surface of southern Africa, Atmos. Chem. Phys., 13, 6421-6428, https://doi.org/10.5194/acp13-6421-2013, 2013.

Slemr, F., Weigelt, A., Ebinghaus, R., Bieser, J., Brenninkmeijer, C. A. M., Rauthe-Schöch, A., Hermann, M., Martinsson, B. G., van Velthoven, P., Bönisch, H., Neumaier, M., Zahn, A., and Ziereis, H.: Mercury distribution in the upper troposphere and lowermost stratosphere according to measurements by the IAGOS-CARIBIC observatory: 2014-2016, Atmos. Chem. Phys., 18, 12329-12343, https://doi.org/10.5194/acp-18-123292018, 2018.

Slemr, F., Martin, L., Labuschagne, C., Mkololo, T., Angot, H., Magand, O., Dommergue, A., Garat, P., Ramonet, M., and Bieser, J.: Atmospheric mercury in the Southern Hemisphere - Part 1: Trend and inter-annual variations in atmospheric mercury at Cape Point, South Africa, in 2007-2017, and on Amsterdam Island in 2012-2017, Atmos. Chem. Phys., 20, 7683-7692, https://doi.org/10.5194/acp-20-7683-2020, 2020.

Stein, A. F., Draxler, R. R., Rolph, G. D., Stunder, B. J. B., Cohen, M. D., and Ngan, F.: NOAA's HYSPLIT Atmospheric Transport and Dispersion Modeling System, B. Am. Meteorol. Soc., 96, 2059-2077, 2015.

Streets, D. G., Horowitz, H. M., Lu, Z., Levin, L., Thackray, C. P., and Sunderland, E. M.: Global and regional trends in mercury emissions and concentrations, 2010-2015, Atmos. Environ., 201, 417-427, 2019.

UNEP: The Minamata Convention on Mercury, available at: http://www.mercuryconvention.org/Countries/tabid/3428/ language/en-US/Default.aspx (last access: 17 June 2019), 2013.

Venter, A. D., Beukes, J. P., van Zyl, P. G., Brunke, E.-G., Labuschagne, C., Slemr, F., Ebinghaus, R., and Kock, H.: Statistical exploration of gaseous elemental mercury (GEM) measured at Cape Point from 2007 to 2011, Atmos. Chem. Phys., 15, 10271-10280, https://doi.org/10.5194/acp-15-10271-2015, 2015.

Weigelt, A., Ebinghaus, R., Manning, A. J., Derwent, R.G., Simmonds, P., Spain, T. G., Jennings, S. G., and Slemr, F.: Analysis and interpretation of 18 years of mercury observations since 1996 at Mace Head, Ireland, Atmos. Environ., 100, 85-93, 2015.

Zahorowski, W., Chambers, S. D., and Henderson-Sellers, A.: Ground-based radon-222 observations and their application to atmospheric studies, J. Environ. Radioactiv., 76, 3-33, 2004. 